\title{
THE ACCOUNTING SYSTEM AS AN INFORMATION BASE FOR BUSINESS PERFORMANCE MANAGEMENT
}

\begin{abstract}
In order to perform tasks a business has been set up since every day it conducts a number of various activities. Actions, accomplishments are processes, achievements, completed goals and company successes. The selection of business activities is preceded by a decision-making process concerning operations, strategies and management. Various information is necessary for taking decisions on managing a business, formulating and implementing strategies. The main information base for business entities is the accounting system. Organization of financial and management accounting in an enterprise should be constructed in such a way as to generate information that is characterized by such features as: timeliness, usability, credibility, economic suitability, measurability, comparability.

The objective of the study is to present possibilities of applying accounting solutions as sources of information for business performance management. The thesis is stated in the statement that "There is no universal set of performance measures adequate for all enterprises, and the management accounting system has instruments that can provide information for managing the achievements". The objective of the article was achieved through analysing literature and information provided on business entities' websites, conducting interviews with accounting and finance department employees as well as studying survey results. The considerations presented in the study, including the results of scientific research, constitute an important contribution to the discussion on the future model of the financial and management accounting system in managing the achievements of a business entity operating in a changing environment.
\end{abstract}

Keywords: accounting, performance management, information.

\section{INTRODUCTION}

Running a business is determined by a range of various activities which reflect entity's performance. Performance is an ambiguous term connected with carrying out specific

\footnotetext{
${ }^{1}$ Beata Sadowska, PhD, Faculty of Management and Economics of Services, University of Szczecin, Szczecin, e-mail: beatasadowska71@wp.pl.

Dr Beata Sadowska, Wydział Zarządzania i Ekonomiki Usług, Uniwersytet Szczeciński, Szczecin, e-mail: beatasadowska71@wp.pl.

2 M.A. Ceslovas Bartkus, Faculty of Social Sciences, Panevezys University of Applied Sciences, Laisves a. 23, Panevezys LT-35200, Lithuania, e-mail: ceslovas.bartkus@ panko.lt.

Mgr Ceslovas Bartkus, Wydział Nauk Społecznych, Uniwersytet Nauk Stosowanych w Panevezys Laisves a. 23, Panevezys LT-35200, Litwa, e-mail: ceslovas.bartkus@panko.lt.
} 
activities as part of a process. T. Kotarbiński claims that "to perform something means to do something so that a thing that has been previously planned takes place"3.

On the basis of available literature, information on entities' websites, surveys and interviews with accounting and finance department employees, it can be stated that in many organizational units performance is not defined and managed, and only the subsystem of financial accounting is used to conduct business activities. Tools of the subsystem of management accounting, as an information base used in performance management, are rarely used by companies, what determines the need to conduct further research on the possibilities and purpose of their application.

The objective of the study is to present possibilities of applying accounting solutions as sources of information for business performance management. The thesis of the study is as follows: "There is no universal set of performance indicators adequate for all companies and the system of management accounting has instruments which can provide information necessary for performance management".

\section{TERM AND TYPES OF PERFORMANCE}

In other words, performance is an activity, a process, an accomplishment, the achieved objective and company's success. One should agree with E. Nowak ${ }^{4}$ that "business performance is an economic category which is ambiguously defined in economic sciences as well as in practical activity. Performance is a term which is present in various disciplines of economics. This category can be found in management, controlling and (management) accounting. In terms of these disciplines, it is more frequently said that there is business performance management, performance measurement and performance evaluation." In practice, it can be observed that there is more and more interest in performance, its measurements and management, but also one can notice that this term is still interpreted ambiguously. In literature on the subject, authors provide various definitions of performance, what is presented in Table 1.

According the author, performance means the effects of conducted activities as part of business, that is offering products and providing services to clients, taking account of not only financial aspects (profit), but also social and environmental ones.

Entities start conducting business activities when there is demand for it. The effect of business activity is achievements offered to some group of users interested in performance. Company's performance means that activities it undertakes determine fulfilling the adopted objectives and gaining better results, including financial results. An organization has achievements when resources it has are effectively used, business processes run smoothly and objectives are successfully fulfilled ${ }^{5}$. Performance is a set of closely related measures, tasks and objectives which require coordination and management.

\footnotetext{
3 T. Kotarbiński, Traktat o dobrej robocie [Treatise on good work], Ossolineum, Warsaw 1982, p. 7.

${ }^{4}$ E. Nowak, Dokonania przedsiębiorstwa jako przedmiot zarzadzania [Business performance as the subject of management] [in:] Zarzadzanie dokonaniami $w$ organizacjach [Business performance management], E. Nowak (ed.), Polskie Wydawnictwo Ekonomiczne S.A., Warsaw 2016, p.11.

${ }^{5}$ E. Nowak, Dokonania przedsiębiorstwa..., p. 11.
} 
Table 1. Definitions of performance by selected authors

\begin{tabular}{|l|l|}
\hline \multicolumn{1}{|c|}{ Author } & \multicolumn{1}{c|}{ Definition } \\
\hline Hilgers $(2008)^{6}$ & $\begin{array}{l}\text { Performance is a result of effectiveness of activities and decisions made } \\
\text { at all organizational levels of a business entity, taking account of needs } \\
\text { of many information user groups and company's stakeholders. }\end{array}$ \\
\hline Krause (2005) & $\begin{array}{l}\text { Performance indicates the level of achievement of objectives or execu- } \\
\text { tion of tasks which for key stakeholders are the main features of com- } \\
\text { pany's activities. Performance is evaluated according to a multidimen- } \\
\text { sional set of measures and indicators. }\end{array}$ \\
\hline Bode $(2008)^{8}$ & $\begin{array}{l}\text { Performance involves activities based on work and means conducting } \\
\text { tasks as part of operational activities. Performance is defined as a result } \\
\text { of company's activities. }\end{array}$ \\
\hline Strąk $(2012)^{9}$ & Business performance is every desired result of entity's activities. \\
\hline Nita $(2009)^{10}$ & $\begin{array}{l}\text { Business performance is a multifaceted economic category which cannot } \\
\text { be narrowed down to results of business activities in financial terms; } \\
\text { a company has achievements when it operates economically, effectively } \\
\text { and efficiently. }\end{array}$ \\
\hline Nowak $(2016)^{11}$ & $\begin{array}{l}\text { Performance is a term which means everything that a company achieves } \\
\text { by conducting activities. Performance can mean states which are consi- } \\
\text { dered to be the results of the undertaken activities. }\end{array}$ \\
\hline
\end{tabular}

Own study on the basis of: D. Hilgers, Performance Management..., p. 32-33; O. Krause, Performance Management..., p. 19; J. Bode, Performance Measurement..., p. 3; T. Strą, Modele dokonań..., p. 113; B. Nita, Rola rachunkowości..., p. 59; M. Nowak, Psychologiczne..., p. 11.

Performance can be defined as an effect or a result of some phenomenon, work, activity for which the criterion should be the fulfilment of the objective a given activity has been undertaken for ${ }^{12}$. Performance involves various fields of business activities and is connected with the implementation of business processes in terms of operations and strategies. A significant element of the description of performance is its identification so that one can obtain answers to fundamental questions which characterize performance, that is:

${ }^{6}$ D. Hilgers, Performance Management. Leistungserfassung und Leistungssteuerung in unternehmen und öffentlichen Verwaltungen, Gabler Edition Wissenschaft, Wiesbaden 2008.

7 O. Krause, Performance Management, Eine Stakeholder-Nutzen-orientierte und Geschäftsprozessbasierte Methode, Technischen Universität, Berlin 2005.

8 J. Bode, Performance Measurement und Management, IGEL, Verlag 2008.

9 T. Strąk, Modele dokonań jednostek sektora finansów publicznych [Performance models of public finance sector entities], Warsaw 2012.

10 B. Nita, Rola rachunkowości zarzadczej we wspomaganiu zarzadzania dokonaniami przedsiębiorstwa [Role of management accounting in supporting business performance management], Publishing House of Wrocław University of Economics, Wrocław 2009.

${ }^{11}$ M. Nowak, Psychologiczne i etyczne aspekty zarzadzania dokonaniami [Psychological and ethical aspects of performance management] [in:] Zarzadzanie dokonaniami w organizacjach [Business performance management], E. Nowak (ed.), Polskie Wydawnictwo Ekonomiczne S.A., Warsaw 2016.

12 M. Kludacz: System pomiaru i oceny dokonań szpitala [Hospital measurement and performance evaluation system], M. Hass-Symotiuk (ed.), Warsaw 2011, p. 64. 
1. What performance is there in an organization?

2. In what field of an organizational structure (department, section, unit, responsibility centres) does performance occur?

3. What entities generate given performance?

4. What resources are used to generate particular performance?

5. What is performed in a given period of time (a month, a quarter, a financial year)?

6. Who is responsible for particular performance?

7. Is there any risk connected with performance?

Answers to the questions posed above enable classifying performance in companies. A basic criterion for the classification of performance is its impact on business entity's activities. On the basis of this criterion, the following should be distinguished ${ }^{13}$ :

- operational performance which results from streamlining activities and strategic performance connected with future business opportunities. Performance in terms of significance for fulfilling organization's objectives can be divided into:

- spectacular performance which results from radical changes in ways a company operates and it is characterized by a high level of risk,

- side performance which results from activities supporting streamlining and is not necessary for ensuring the development of a business entity.

The next criterion for classifying performance in the possibility of measuring its intensity as presented in Figure 1.

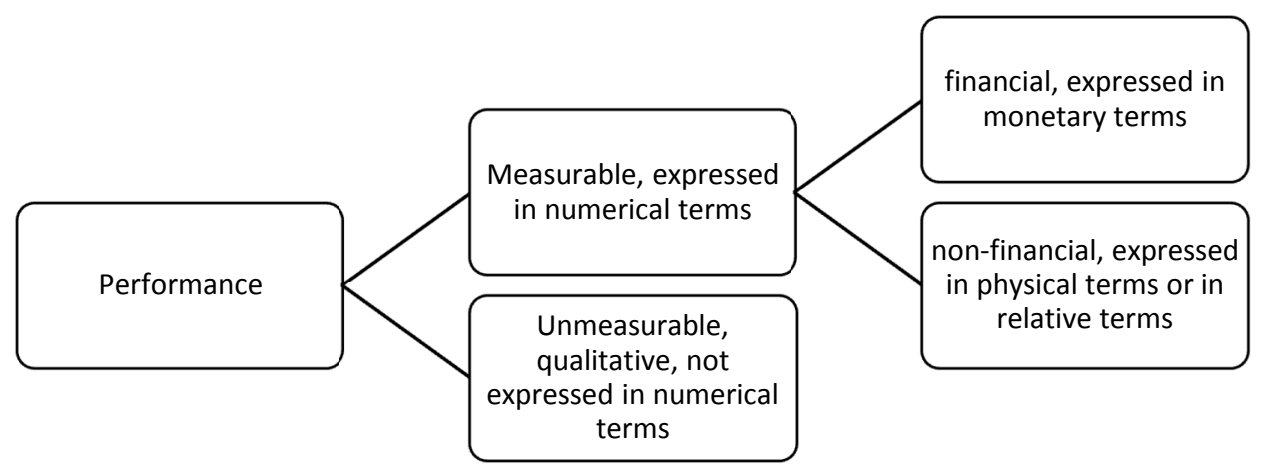

Figure 1. The classification of performance according to the measurement of its intensity

Source: own work on the basis of M. Nowak, Dokonania przedsiębiorstwa..., p. 13.

Business performance can be also classified according to other criteria, among other things: generic criterion, business process phases, fields of operations (purchase, sale, logistics, accounting, marketing), activity centres, management level.

In Polish literature, the following authors deal with the term and types of business performance as well as its relations with the information system of accounting: R. Kowalak

\footnotetext{
${ }^{13}$ More about the classification of performance according to various criteria: Bradley 2006.
} 
$2016^{14}$, M. Nieplowicz $2016^{15}$, B. Nita2016 ${ }^{16}$, B. Sadowska $2016^{17}$, M. Czerny $2015^{18}$, T. Dyczkowski $2015^{19}$, M. Kowalewski $2015^{20}$, M. Nowak $2015^{21}$, G. Lew $2015^{22}$, P. Szczypa $2015^{23}$.

${ }^{14}$ R. Kowalak, Mierniki dokonań w kokpitach menedżerskich przedsiębiorstwa [Performance indicators in corporate dashboards] [in:] Wyzwania w zarzadzaniu kosztami i dokonaniami [Challenges in cost and performance management], R. Kowalak, M. Kowalewski, P. Bednarek (eds.), Research Papers of Wrocław University of Economics No. 442, Publishing House of Wrocław University of Economics, Wrocław 2016, p. 213-221.

15 M. Nieplowicz, Analiza porównawcza zastosowania zrównoważonej karty wyników w podmiotach leczniczych [Comparative analysis of the balanced scorecard in healthcare entities] [in:] Wyzwania w zarzadzaniu kosztami i dokonaniami [Challenges in cost and performance management], R. Kowalak, M. Kowalewski, P. Bednarek (eds.), Research Papers of Wrocław University of Economics No. 442, Publishing House of Wrocław University of Economics, Wrocław 2016, p. 317-321.

16 B. Nita, Krytyka zrównoważonej karty wyników [Criticque of the balanced scorecard] [in:] Wyzwania $w$ zarzadzaniu kosztami i dokonaniami [Challenges in cost and performance management], R. Kowalak, M. Kowalewski, P. Bednarek (eds.), Research Papers of Wrocław University of Economics No. 442, Publishing House of Wrocław University of Economics, Wrocław 2016, p. 325-333.

17 B. Sadowska: System pomiaru dokonań W PGL LP - proces przygotowania i implementacji [Performance measurement system in the State Forests National Forest Holding - the preparation and implementation process] [in:] Wyzwania $w$ zarzadzaniu kosztami $i$ dokonaniami [Challenges in cost and performance management], R. Kowalak, M. Kowalewski, P. Bednarek (eds.), Research Papers of Wrocław University of Economics No. 442, Publishing House of Wrocław University of Economics, Wrocław 2016, p. 399-407.

${ }_{18}$ M. Czerny, Pomiar dokonań w bankach islamskich [Performance measurement in Islamic banks] [in:] Zarzadzanie kosztami $i$ dokonaniami [Cost and performance management], E. Nowak, M. Kowalewski, (eds.), Research Papers of Wrocław University of Economics No. 398, Publishing House of Wrocław University of Economics, Wrocław 2015, p. 105-111.

19 T. Dyczkowski, Mierniki dokonań organizacji pożytku publicznego. Możliwości i ograniczenia stosowania [Performance indicators in public benefit organizations. Application possibilities and limitations] [in:] Zarzadzanie kosztami $i$ dokonaniami [Cost and performance management], E. Nowak, M. Kowalewski, (eds.), Research Papers of Wrocław University of Economics No. 398, Publishing House of Wrocław University of Economics, Wrocław 2015, p. 146-158.

${ }^{20}$ M. Kowalewski, Pomiar i raportowanie dokonań na poziomie strumienia [Performance measurement and reporting at the value stream level] [in:] Zarzadzanie kosztami i dokonaniami [Cost and performance management], E. Nowak, M. Kowalewski, (eds.), Research Papers of Wrocław University of Economics No. 398, Publishing House of Wrocław University of Economics, Wrocław 2015, p. 260-268.

${ }^{21}$ M. Nowak: Etyka controllingowego pomiaru dokonań w świetle filozofii utylitarystycznej-zarys koncepcji [Performance measurement ethics based on utilitarian theories - concept outline], Theoretical Journal of Accounting 82 (138), Research Council of the Accountants Association in Poland, Warsaw 2015, p. 113-128.

${ }^{22}$ G. Lew, Pomiar dokonań relacji z klientami w przedsiębiorstwach handlowych [Performance measurement in terms of relations with clients in trading companies] [in:] Zarzadzanie kosztami i dokonaniami [Cost and performance management], E. Nowak, M. Kowalewski, (eds.), Research Papers of Wrocław University of Economics No. 398, Publishing House of Wrocław University of Economics, Wrocław 2015, p. 289-297.

${ }^{23}$ P. Szczypa, Koncepcja pomiaru osiagnięć w Pol-Eko Aparatura spótka jawna [The concept of performance management in Pol-Eko Aparatura spótka jawna], [in:] Zarządzanie kosztami 
The issues of performance are discussed, among others, in the following monographs: M. Hass-Symotiuk (ed.) $2011^{24}$, A. Niemiec (ed.) $2016^{25}$, W. Skoczylas, A. Niemiec (eds.) $2016^{26}$, E. Nowak (ed.) $2012^{27}$, T. Strąk $2012^{28}$.

\section{INFORMATION SYSTEM OF ACCOUNTING}

Accounting is a business language. It is a system providing information on a financial situation, performance, results and activities of an organization. Accounting from the perspective of the economic theory of information and the economic theory of decision making is the information system of a business entity ${ }^{29}$. A significant role in the organization of the information system of accounting is played by usefulness and credibility. From the point of view of a user of information, information is useful when it satisfies needs of a given user and determines their financial and non-financial (social or ecological) benefits. As far as users of information are concerned, accounting is divided into two subsystems ${ }^{30}$ : financial accounting and management accounting as shown in Figure 2.

A fundamental function of the accounting system is the information function ${ }^{31}$. It involves creating information sets, processing and presenting them to various groups of users, and determines making efficient and effective management decisions. One should agree with A. Karmańska ${ }^{32}$ who states that "by carrying out its functions, accounting is above all

i dokonaniami [Cost and performance management], E. Nowak, M. Kowalewski, (eds.), ResearchPapers of Wrocław University of Economics No. 398, Publishing House of Wrocław University of Economics, Wrocław 2015, p. 441-449.

${ }^{24}$ System pomiaru i oceny dokonań szpitala [Hospital measurement and performance evaluation system], M. Hass-Symotiuk (ed.), Wolters Kluwer Polska Sp. z o.o., Warsaw 2011.

${ }^{25}$ System pomiaru dokonań w przedsiębiorstwach [Performance measurement system in companies], A. Niemiec (ed.), CeDeWu Sp. z o.o., Warsaw 2016.

${ }^{26}$ Leksykon mierników dokonań [Performance indicators lexicon], W. Skoczylas, A. Niemiec (eds.), CeDeWu Sp. z o.o. , Warsaw2016.

${ }^{27}$ Pomiar i raportowanie dokonań przedsiębiorstwa [Business performance measurement and reporting], E. Nowak (ed.), CeDeWu Sp. z o.o., Warsaw 2012.

${ }^{28}$ T. Strąk, Modele dokonań....

${ }^{29}$ R. Crandall, Information Economics and Its Implications for the Further Development of Accounting Theory, “Accounting Review“, July 1969; G. Feltham: The Value of Information, „Accounting Review", October 1968.

30 A. Szydełko, Rachunkowość jako baza informacyjna zarzadzania dokonaniami [Accounting as an information base for performance management] [in:] Zarzadzanie dokonaniami $w$ organizacjach [Business performance management], E. Nowak (ed.), Polskie Wydawnictwo Ekonomiczne S.A., Warsaw 2016, p. 160; A. Lulek, Od przesztości do przyszłości - ewolucja rachunkowości i jej pojęcia [From past to future - the evolution of accounting and its concept] [in:] Dylematy i perspektywy rozwoju finansów i rachunkowości [Dilemmas and perspectives of the development of finance and accounting], P. Szczypa, A. Zimny (eds.), Publishing House of Wyższa Szkoła Zawodowa in Konin, Konin 2017, p. 95.

31 Apart from the information function, accounting has other functions, for example: controlling, reporting, analytical and interpretive, statistical.

32 A. Karmańska, System informacyjny we wspótczesnym przedsiębiorstwie [Information system in a modern enterprise] [in:] Rachunkowość zarządcza i rachunek kosztów w systemie informacyjnym przedsiębiorstwa [Management accounting and cost accounting in a corporate information system], A. Karmańska (ed.), Difin, Warsaw 2006, p. 51. 


Financial accounting $\left\{\begin{array}{l}\text { - provides information of a financial character mainly to external } \\ \text { users who include: investors, central and local government } \\ \text { authorities, shareholders and creditors. It provides mainly } \\ \text { information concerning the past (historical one) }\end{array}\right.$

Figure 2. Accounting subsystems

Source: own work.

the information system in which the main part is played by economic information or financial information and whose basic goal is to satisfy information needs of various groups of stakeholders". The structure of the information system of accounting is presented in Figure 3. The subsystem of financial accounting generates mainly information for external users and uses such basic tools as: balance sheet, profit and loss account, notes to financial statements, statement of changes in equity, cash flow statement, activity report.

\begin{tabular}{|c|c|c|}
\hline \multirow{9}{*}{$\begin{array}{l}\text { Accounting - the } \\
\text { information } \\
\text { system }\end{array}$} & \multirow[t]{4}{*}{ Collecting data } & Observing and measuring \\
\hline & & Valuating \\
\hline & & Documenting \\
\hline & & Operational planning and budgeting \\
\hline & \multirow[t]{2}{*}{ Processing data } & Recording and settling \\
\hline & & Calculating \\
\hline & \multirow[t]{3}{*}{ Presenting information } & Financial statements \\
\hline & & Analysing and reporting \\
\hline & & Strategic budgeting \\
\hline
\end{tabular}

Figure 3. Information system of accounting

Source: own work.

The subsystem of management accounting (if it is used in a given company) provides management information concerning values for clients, employees and shareholders. It supports making logistic decisions connected with company's social and ecological activities 
(the organization of inventory, transport processes, work in responsibility centres). The scope of the organization of the accounting system in a company is presented in Figure 4.

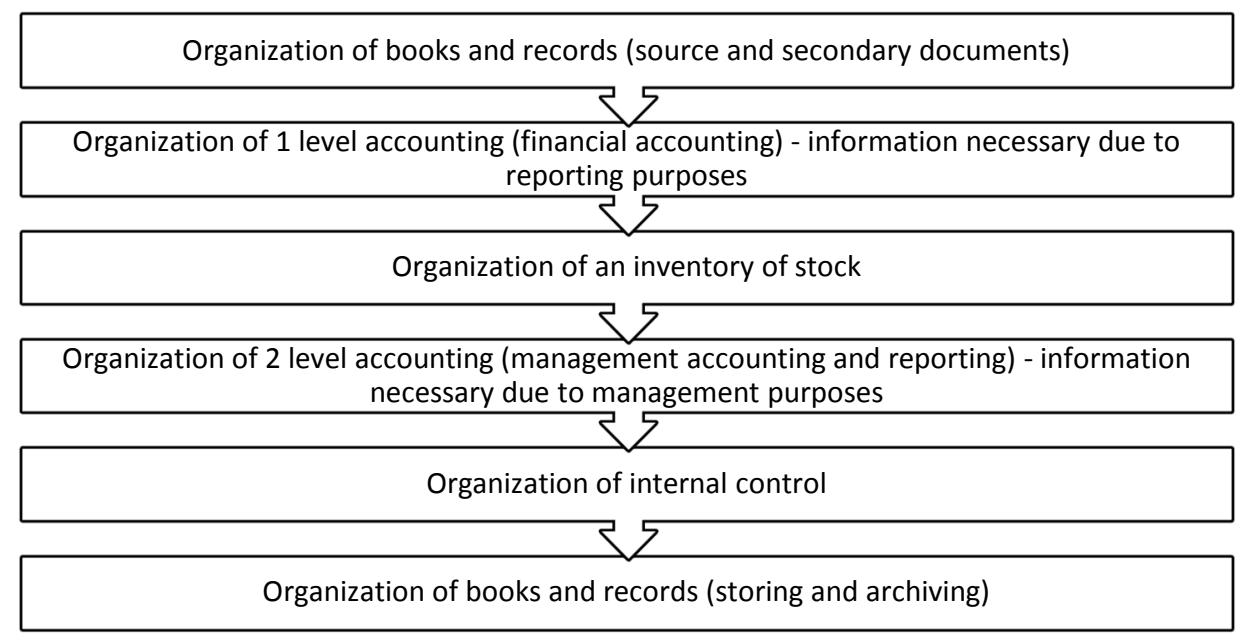

Figure 4. The scope of the organization of the accounting system in a company

Source: own work.

The organization of financial and management accounting in a company should be executed in such a way so that it provides information which has the following characteristics: timeliness, relevance, reliability, economic usefulness, measurability, comparability.

It is also worth mentioning that the asymmetry of information causes that one user is better informed that the other, what makes them take more accurate decisions, thus satisfy their needs in a better way. The asymmetry of information also causes that some stakeholders cannot ascertain whether information they have is reliable, relevant and useful in the decision-making process ${ }^{33}$. It is determined by information noise which significantly hinders business performance management.

\section{PERFORMANCE MANAGEMENT WITH THE USE OF ACCOUNTING TOOLS}

Accounting as the information system generates and provides various information for the management of a business entity. The scope and type of information stem from demand for it. Information is generated in the subsystems of financial and management accounting ${ }^{34}$.

${ }^{33}$ W. Scott, Financial Accounting Theory, Prentice Hall, London 1997, p. 3.

34 The name of the accounting subsystem, "management accounting" was given after publishing first handbooks in the USA entitled: Managerial Accounting and Management Accounting [Vatter 1950], [Robnett el al. 1951], [Antony 1955 (989)]. See: A. Szychta, Rachunek kosztów i rachunkowość zarzadcza [Cost accounting and management accounting] [in:] Wspótczesne nurty badawcze $w$ rachunkowości [Contemporary research trends in accounting], I. Sobańska, P. Kobalski (eds.), Publishing House of University of Łódź, Łódź 2012, p. 113. 
The subsystem of financial accounting haslimited possibilities of providing information for the purpose of organization's management. As A. Szydełko ${ }^{35}$ rightly observes, this system "objective is to create information necessary for developing financial indicators. Categories making up fundamental financial indicators which are subject to direct measurement as part of financial accounting are resources, results of activity and a cash flow".

The main tool for generating information for the purpose of business performance management in the subsystem of financial accounting is financial statements ${ }^{36}$. Financial statements present figures expressed in terms of value (most often in PLN) which synthetically characterize a financial situation and assets as well as the result of a given company's activities. The subsystem of management accounting has many tools which can be applied to performance management. The selection of management accounting methods and instruments in a specific business entity is determined by such individual factors as:

- a sector in which a given organization operates, e.g. public finance sector (schools, budgetary divisions, such as: Housing Management Department, Water and Sewage Company); private sector (limited liability companies, joint-stock companies, microenterprises); non-profit sector (associations),

- an organizational structure of a business entity,

- a management model (democratic, authoritarian),

- employees' level of knowledge and skills,

- communication and coordination levels.

Thanks to managers' decisions, availability of information and employee commitment, business performance management with the use of the accounting system leads to more effective results of business activities and builds organization's good reputation in its internal and external environment.

The research on the accounting system as an information base for business performance management was conducted among people employed in the enterprise sector and public finance sector. Respondents are employed in limited liability companies, municipal companies, budgetary units, budgetary divisions, private enterprises and a health care centre.

The survey, which consisted of 8 questions, was sent to 42 people who were final-year students or are currently students of postgraduate studies of Budgetary Accounting as well as Management Accounting and Controlling in the Faculty of Management and Economics of Services at the University of Szczecin. As many as 40 students completed the survey, that is $95.23 \%$ of the research sample. The largest group of respondents $(60 \%)$ constitute people employed in the public finance sector. The research findings are as follows:

1. 35 business entities have accounting policies (principles), whereas in 26 entities performance is described in accounting policies.

2. $75 \%$ of respondents admit that in their organizations only financial accounting tools are used which to some extent provide information on performance in an organiza-

35 A. Szydełko, Rachunkowość..., p. 164.

${ }^{36}$ Financial statements involve: introduction to the financial statements, profit and loss account (income statement), balance sheet, statement of changes in equity, cash flow statement and notes to financial statements. 
tion. Simultaneously, $50 \%{ }^{37}$ of respondents claim that in that regard they do not use management accounting instruments ${ }^{38}$.

3. According to the surveyed postgraduate students, tools of financial accounting as an information base for business performance management which are most often used are as follows: balance sheet, profit and loss account and activity report.

4. Only $7.5 \%{ }^{39}$ of respondents use tools of the subsystem of cost accounting as an information base for business performance management and $35 \%$ of respondents use these instruments to a limited extent.

5. $72.5 \%$ of respondents state that the subsystem of controlling is not used for business performance management in entities where they work.

6. $75 \%$ of respondents admit that they do not use any management accounting tools as an information base for business performance management. Only few ${ }^{40}$ representatives of business practice use:

- variable cost calculation and price calculation,

- activity-based costing,

- decision calculus under conditions of risk,

- quality management tools ${ }^{41}$.

7. Respondents' answers to the question: "Should modern organizations, in your opinion, use management accounting tools as an information base for business performance management?" were as follows:

- $32.5 \%$ of respondents indicated activity-based accounting as the most useful management accounting tool which can be applied as a base of information on business performance,

- $30 \%$ of students suggested using variable cost calculation and price calculation,

- $17.5 \%$ of respondents could use a balanced scorecard and activity-based budgets.

8. According to respondents, the following factors pose the greatest barriers to implementing new tools of the accounting system as an information base for business performance management:

- lack of employees' experience in using a given accounting tool,

- lack of proper software and high costs of system modification,

- a low level of employees' knowledge, skills and qualifications,

- lack of awareness of the management.

${ }^{37}$ Mostly, such answers were given by respondents working in the public finance sector.

${ }^{38}$ Once again, this study and the conducted survey research confirm that entities operating in the public finance sector, including commercial companies and partnerships, rarely use management accounting and controlling instruments. In this respect, still mainly obligatory tools of the subsystem of financial accounting are used. Although the management in the public finance sector is more and more aware, one can still observe resistance to the idea of implementing modern methods and accounting instruments.

39 These are mainly representatives of the enterprise sector.

${ }^{40}$ Only representatives of the enterprise sector use the listed management accounting tools.

41 The representatives of the public finance sector preferred variable cost calculation and price calculation. Activity-based accounting, quality management tools and decision calculus under conditions of risk are used by the private sector entities and commercial companies and partnerships. The representatives of the private sector also pointed out that in the subsystem of accounting they use a balanced scorecard and keep accounting records in responsibility centres. 


\section{CONCLUSION}

Performance measurement poses a lot of challenges to the modern accounting system which is a main information base for performance management. Performance management requires applying many diverse measurement methods and instruments which have to be individually selected by a business entity.

This study confirms that the issue is still valid from the point of view of science and business practice. Special attention should be paid to the fact that there are significant differences in using optional accounting tools between the enterprise sector and the public finance sector. Business entities from the enterprise sector increasingly more often use management accounting tools to generate and report information for the purpose of performance management, whereas in the public finance sector there is still a lot to be done in that regard. Analysing literature and information provided on business entities' websites, conducting interviews with accounting and finance department employees as well as studying survey results, the author proved the following research thesis: "There is no universal set of performance indicators adequate for all companies and the system of management accounting has instruments which can provide information necessary for performance management". Thus the fundamental objective of the study was achieved through presenting possibilities of applying accounting solutions as sources of information in business performance management.

The author believes that the deliberations in the study, including the research findings, are a valuable contribution to the discussion of the future model of the financial and management accounting systems for performance management in business entities operating in a changeable environment. This issue is not new, however, it is still valid in terms of solving dilemmas in the enterprise sector as well as in entities of the public finance sector in particular.

\section{REFERENCES}

1. Bode J., Performance Measurement und Management, IGEL, Verlag 2008.

2. Crandall R., Information Economics and Its Implications for the Further Development of Accounting Theory, “Accounting Review“, July 1969.

3. Czerny M., Pomiar dokonań w bankach islamskich [Performance measurement in Islamic banks] [in:] Zarządzanie kosztami $i$ dokonaniami [Cost and performance management], E. Nowak, M. Kowalewski, (eds.), Research Papers of Wrocław University of Economics No. 398, Publishing House of Wrocław University of Economics, Wrocław 2015.

4. Dyczkowski T., Mierniki dokonań organizacji pożytku publicznego. Możliwości i ograniczenia stosowania [Performance indicators in public benefit organizations. Application possibilities and limitations] [in:] Zarzadzanie kosztami i dokonaniami [Cost and performance management], E. Nowak, M. Kowalewski, (eds.), Research Papers of Wrocław University of Economics No. 398, Publishing House of Wrocław University of Economics, Wrocław 2015.

5. Feltham G., The Value of Information, „, Accounting Review”, October 1968.

6. Karmańska A., System informacyjny we wspótczesnym przedsiębiorstwie [Information system in a modern enterprise] [in:] Rachunkowość zarzaddza i rachunek kosztów w systemie informacyjnym przedsiębiorstwa [Management accounting and cost accounting in a corporate information system], A. Karmańska (ed.), Difin, Warsaw 2006. 
7. Hilgers D., Performance Management. Leistungserfassung und Leistungssteuerung in unternehmen und öffentlichen Verwaltungen, Gabler Edition Wissenschaft, Wiesbaden 2008.

8. Kludacz M., System pomiaru i oceny dokonań szpitala [Hospital measurement and performance evaluation system], M. Hass-Symotiuk (ed.), Wolters Kluwer Polska Sp. z o.o., Warsaw 2011.

9. Kotarbiński T., Traktat o dobrej robocie [Treatise on good work], Ossolineum, Warsaw 1982.

10. Kowalak R., Mierniki dokonań w kokpitach menedżerskich przedsiębiorstwa [Performance indicators in corporate dashboards] [in:] Wyzwania w zarzadzaniu kosztami $i$ dokonaniami [Challenges in cost and performance management], R. Kowalak, M. Kowalewski, P. Bednarek (eds.), Research Papers of Wrocław University of Economics No. 442, Publishing House of Wrocław University of Economics, Wrocław 2016.

11. Kowalewski M., Pomiar i raportowanie dokonań na poziomie strumienia [Performance measurement and reporting at the value stream level] [in:] Zarzadzanie kosztami $i$ dokonaniami [Cost and performance management] E. Nowak, M. Kowalewski, (eds.), Research Papers of Wrocław University of Economics No. 398, Publishing House of Wrocław University of Economics, Wrocław 2015.

12. Krause O., Performance Management, Eine Stakeholder-Nutzen-orientierte und Geschäftsprozess-basierte Methode, Technischen Universität, Berlin 2005.

13. Leksykon mierników dokonań [Performance indicators lexicon], W. Skoczylas, A. Niemiec (eds.), CeDeWu Sp. z o.o, Warsaw 2016.

14. Lew G., Pomiar dokonań relacji z klientami w przedsiębiorstwach handlowych [Performance measurement in terms of relations with clients in trading companies] [in:] Zarzadzanie kosztami i dokonaniami [Cost and performance management], E. Nowak, M. Kowalewski, (eds.), Research Papers of Wrocław University of Economics No. 398, Publishing House of Wrocław University of Economics, Wrocław 2015.

15. Lulek A., Od przeszłości do przyszłości - ewolucja rachunkowości i jej pojęcia [From past to future - the evolution of accounting and its concept] [in:] Dylematy i perspektywy rozwoju finansów i rachunkowości [Dilemmas and perspectives of the development of finance and accounting], P. Szczypa, A. Zimny (eds.), Publishing House of Wyższa Szkoła Zawodowa in Konin, Konin 2017.

16. Nieplowicz M., Analiza porównawcza zastosowania zrównoważonej karty wyników w podmiotach leczniczych [Comparative analysis of the balanced scorecard in healthcare entities] [in:] Wyzwania w zarzadzaniu kosztami i dokonaniami [Challenges in cost and performance management], R. Kowalak, M. Kowalewski, P. Bednarek (eds.), Research Papers of Wrocław University of Economics No. 442, Publishing House of Wrocław University of Economics, Wrocław 2016.

17. Nita B., Rola rachunkowości zarzadczej we wspomaganiu zarzadzania dokonaniami przedsiębiorstwa [Role of management accounting in supporting business performance management], Publishing House of Wrocław University of Economics, Wrocław 2009.

18. Nita B., Krytyka zrównoważonej karty wyników [Criticque of the balanced scorecard] [in:] Wyzwania $w$ zarzadzaniu kosztami $i$ dokonaniami [Challenges in cost and performance management], R. Kowalak, M. Kowalewski, P. Bednarek (eds.), Research Papers of Wrocław University of Economics No. 442, Publishing House of Wrocław University of Economics, Wrocław 2016.

19. Nowak M., Etyka controllingowego pomiaru dokonań w świetle filozofii utylitarystycznejzarys koncepcji [Performance measurement ethics based on utilitarian theories - concept 
outline], Theoretical Journal of Accounting 82 (138), Research Council of the Accountants Association in Poland, Warsaw 2015.

20. Nowak M., Psychologiczne $i$ etyczne aspekty zarzadzania dokonaniami [Psychological and ethical aspects of performance management] [in:] Zarzadzanie dokonaniami w organizacjach [Business performance management], E. Nowak (ed.), Polskie Wydawnictwo Ekonomiczne S.A., Warsaw 2016.

21. Nowak M., Dokonania przedsiębiorstwa jako przedmiot zarzązania [Business performance as the subject of management] [in:] Zarzadzanie dokonaniami w organizacjach [Business performance management], E. Nowak (ed.), Polskie Wydawnictwo Ekonomiczne S.A., Warsaw 2016.

22. Pomiar i raportowanie dokonań przedsiębiorstwa [Business performance measurement and reporting], E. Nowak (ed.), CeDeWu Sp. z o.o., Warsaw 2012.

23. Sadowska B., System pomiaru dokonań W PGL LP-proces przygotowania i implementacji [Performance measurement system in the State Forests National Forest Holding - the preparation and implementation process] [in:] Wyzwania $w$ zarzadzaniu kosztami $i$ dokonaniami [Challenges in cost and performance management], R. Kowalak, M. Kowalewski, P. Bednarek (eds.), Research Papers of Wrocław University of Economics No. 442, Publishing House of Wrocław University of Economics, Wrocław 2016.

24. Scott W., Financial Accounting Theory, Prentice Hall, London 1997.

25. Strąk T., Modele dokonań jednostek sektora finansów publicznych [Performance models of public finance sector entities], Difin, Warsaw 2012.

26. System pomiaru i oceny dokonań szpitala [Hospital measurement and performance evaluation system], M. Hass-Symotiuk (ed.), Wolters Kluwer Polska Sp. z o.o., Warsaw 2011.

27. System pomiaru dokonań w przedsiębiorstwach [Performance measurement system in companies], A. Niemiec (ed.), CeDeWu Sp. z o.o, Warsaw 2016.

28. Szczypa P., Koncepcja pomiaru osiagnięć w Pol-Eko Aparatura spótka jawna [The concept of performance management in Pol-Eko Aparatura spótka jawna], [in:] Zarzadzanie kosztami $i$ dokonaniami [Cost and performance management], E. Nowak, M. Kowalewski, (eds.), Research Papers of Wrocław University of Economics No. 398, Publishing House of Wrocław University of Economics, Wrocław 2015.

29. Szychta A., Rachunek kosztów i rachunkowość zarządcza [Cost accounting and management accounting] [in:] Wspótczesne nurty badawcze w rachunkowości [Contemporary research trends in accounting], I. Sobańska, P. Kobalski (eds.), Publishing House of University of Łódź, Łódź 2012.

30. Szydełko A., Rachunkowość jako baza informacyjna zarządzania dokonaniami [Accounting as an information base for performance management] [in:] Zarzadzanie dokonaniami w organizacjach [Business performance management], E. Nowak (ed.), Polskie Wydawnictwo Ekonomiczne S.A., Warsaw 2016.

31. Zarzadzanie dokonaniami $w$ organizacjach [Business performance management], E. Nowak (ed.), Polskie Wydawnictwo Ekonomiczne S.A., Warsaw 2016. 


\section{SYSTEM RACHUNKOWOŚCI JAKO BAZA INFORMACYJNA ZARZĄDZANIA DOKONANIAMI PRZEDSIĘBIORSTWA}

Przedsiębiorstwo w celu wykonywania zadań, do jakich zostało powołane, realizuje codziennie wiele różnorodnych działań. Wybór dotyczący realizacji działań i dokonań jest poprzedzony procesem podejmowania decyzji, w tym decyzji operacyjnych, strategicznych oraz zarządczych Do podejmowania decyzji dotyczących kierowania przedsiębiorstwem, do formułowania i realizacji strategii są niezbędne różnorodne informacje. Podstawową bazą informacyjną w jednostkach gospodarczych jest system rachunkowości. Celem opracowania jest wskazanie możliwości zastosowania rozwiązań z zakresu rachunkowości jako źródła informacji w zarządzaniu dokonaniami przedsiębiorstwa. Cel artykułu osiągnięto studiując literaturę, informacje przedstawione na stronach internetowych jednostek gospodarczych, przeprowadzonych wywiadach z pracownikami działów finansowo-księgowych oraz opracowując wyniki badań ankietowych.

Słowa kluczowe: rachunkowość, zarządzanie dokonaniami, informacja.

DOI: $10.7862 /$ rz.2018.hss.85

Tekst złożono $w$ redakcji: czerwiec $2018 \mathrm{r}$.

Tekst przyjęto do druku: grudzień 2018 r. 